\title{
Digitalisering af OSKE - En digitaliseret eksamen på godt og ondt
}

\section{Kristian Krogh}

PhD studerende

Center for Medical Education, Aarhus University, Aarhus.

\section{Eivind O. Simonsen}

IT medarbejder

Center for Medical Education, Aarhus University, Aarhus

\section{Mads R. Dahl}

$\mathrm{PhD}, \mathrm{Ml}$

Center for Medical Education, Aarhus University, Aarhus
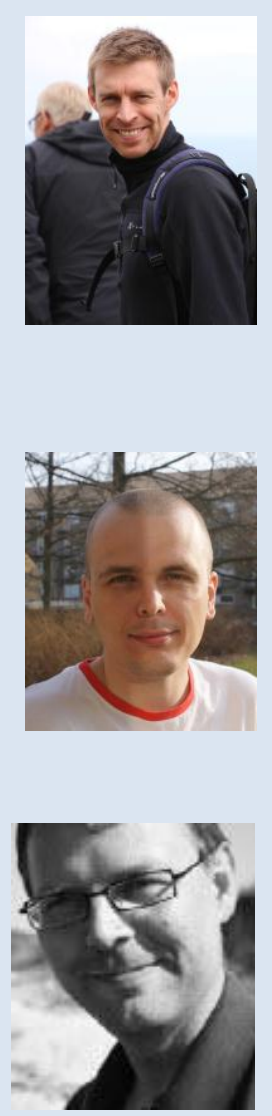

\section{Ulla B. Knudsen}

\section{Professor, Ledende overlæge}

Fertility Clinic/Center for Preimplantation Genetic

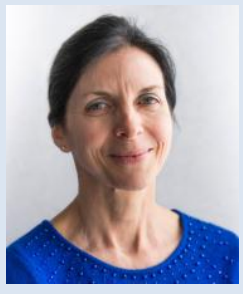

Diagnosis, Aaurhus Universitets Hospital, Aarhus 


\section{Indledning}

Videnskabsministeriet udgav i 2010 en rapport om digitale eksaminer på universiteterne (Bygningsstyrelsen, 2010), hvori udfordringer og anbefalinger vedrørende digitale eksamener ved danske universiteter blev belyst. Denne rapport kom, som opfølgning på regeringens målsætning fra 2007 (III, 2007), om at
"Al skriftlig kommunikation mellem studerende og uddannelsesinstitutioner skal foregå elektronisk, og alle studerende på videregående uddannelser skal have mulighed for at aflevere skriftlige opgaver elektronisk."

Et fælles udspil fra regeringen, KL og danske regioner angående den fællesoffentlige digitaliseringsstrategi (Økonomistyrelsen, 2011) fastlægger, at

\section{"Derfor skal eksamensformerne udvikles og tilpasses den digitale tidsalder. Og den teknologiske infrastruktur skal opgraderes, så de skriftlige prøver senest i 2013 kan gennemføres uden brug af blyant og papir."}

Vi har tidligere beskrevet udfordringerne i forbindelse med digitaliseringen af multiple choice eksamen (MCQ) ved medicin studiet, Health, Aarhus Universitet (Ortind, Krogh, \& Dahl, 2013). Udgangspunktet for udviklingen af en digital MCQ var funderet i planlægningen af en digitaliseret Objektiv Struktureret Klinisk Eksamen (OSKE) som på daværende tidspunkt var blevet udsat. Denne OSKE er nu gennemført for første gang digitalt på ved medicin studiet, Health, Aarhus Universitet.

Denne artikel er udformet som et deskriptivt studie af den digitale OSKE ved medicin studiet, Health, Aarhus Universitet, samt logistikken forbundet med denne eksamensform. Herudover vil vi beskrive en case fra det digitaliserede simulerede laboratorium, og sætte denne ind i en OSKE kontekst.

\section{Objektiv Struktureret Klinisk Eksamen}

OSKE er en eksamensform, som bliver anvendt inden for mange sundhedsvidenskabelige fag. Eksamenen består at en række stande, hvor eksaminanden på hver stand skal forholde sig til en konkret klinisk case. Efter 8-10 minutters eksamination roterer 
eksaminanderne til en ny stand. Hele eksamensforløbet foregår over 15-20 rotationer. Det, at eksaminanderne skal forholde sig til mange forskellige cases, og derved bliver bedømt af forskellige eksaminatorer, gør, at eksamensforløbet bliver objektivt i den forstand, at det ikke er kendskabet - eller mangel på samme - til en bestemt case, som bliver afgørende for den endelige karakter.

På OSKE ved Aarhus Universitet uddeles der ved hver stand to forskellige scorer: én, som tager sigte på de faktuelle færdigheder vedr. casen, og én, som tager sigte på eksaminators subjektive vurdering af denne studerendes evner, som kommende læge. Hvor den subjektive vurdering gives på en enkelt skala, så består den faktuelle score af en række underpunkter (typisk 2-6), hvor den studerende vurderes ud fra en række underspørgsmål med relevans for casen. Et eksempel kunne være evnen til at udføre en rektalundersøgelse (endetarmsundersøgelse)(Skills, 2014).

\section{Den analoge OSKE eksamen}

Scoring ved OSKE foregået hyppigt på papir. Fordelen ved en papirs eksamen er, at den er forholdsvis enkel at klargøre og administrere. Ulempen er, at der er forholdsvis megen administration.

På 11. semesters OSKE på Health, Aarhus Universitet består en OSKE af 14 stande (der afholdes også en MCQ eksamen, så samlet set består 11. semesters eksamen af en OSKE og en MCQ). I papirs form består svararket til hver stand af ét til tre A4-ark, så i gennemsnit vil der være 28 A4-ark pr. studerende. En eksamen består i dag af ca. 150 studerende, så hver eksamen vil i gennemsnit generere 4200 stk. A4-ark. Med øget optag samt fremdriftsreform, så vil antallet af studerende stige støt de næste semestre, og nå op på 200 studerende på hvert semester. Hvorved papirmængden vil stige fra 4200 til 5600 stk. A4-ark.

Til en papirbaseret eksamen skal alle disse papirer samles, og manuelt indtastes i en eller anden form for bogholderi, som typisk består af et regneark (fx. Excel), hvor den enkelte score for hver studerende sidenhen danner baggrund for udregning af en karakter. Da en stand i gennemsnit består fire underpunkter til den faktuelle score, og et punkt til den subjektive vurdering, så vil der med 175 studerende og 14 stande skulle foretages 12250 manuelle indtastninger i regnearket, før karakteren kan udregnes og gives. 
Arbejdet ved at indtaste data, samt sikre sig, at de indtastede data er korrekte, varer et par dage. Selv med de mest omhyggelige indtastere kan risikoen for slåfejl ikke elimineres. Selv med dobbelttastninger af data kan der være tvivl om den endelige karakters validitet, hvilke et komparativt studie imellem analog og digital OSKE i høj grad viste sig som et analogt problem (Schmitz, Zimmermann, Gaunt, Stolze, \& Schär, 2011).

\section{Den digitale OSKE eksamen}

Mange problemstillinger ved den analoge OSKE elimineres ved en digitalisering af eksamen (Harden, 2013; Jalali, Trottier, \& Tremblay, 2012). Hvilke også var den primær bevæggrund for at digitalisere denne OSKE. Ved den digitale OSKE gemmes data løbende under eksamen, og derfor er der ikke behov for ekstra indtastninger efter eksamenen. Herved elimineres en af fejlkilderne ved af de indtastede data og validiteten øges. Desuden kan udregningen af karakteren foregå umiddelbart efter eksamenen.

I forbindelse med en digitalisering af eksamener skal man tage stilling til, hvorvidt man ønsker at anvende en standard løsning, som kan købes fra et firma eller om man ønsker at udvikle sit eget system. Ved Health, Aarhus Universitet blev det valg at udvikle vores eget system. Begrundelse for dette gik primært på to facetter:

1.

De kommercielle løsninger anvendte alle sammen på beslutningstidspunktet en løsning, hvor data blev gemt i en cloud baseret tjeneste. Problemet med dette er, at der er nogle juridisk forhold omkring person følsomme data, hvordan og hvor disse opbevares. Der kunne på daværende tidspunkt med de kommercielle løsninger ikke opnås sikkerhed for at disse forhold kunne imødekommes på en forsvarlig måde.

2. Ved at udvikle vores egen løsning har vi opnået fuldt kontrol over systemet, samt kan lave tilføjelser og rettelser efter behov, samt sikre forsvarlig opbevaring af data. Hvorfor det ligeledes er nemmere at imødekomme de ønsker og tilføjelser, som de enkelte eksaminatorer måtte have.

Vores eksamenssystem er udviklet som en hjemmeside, hvor de enkelte eksamensstande logger ind for at starte eksaminationen. Hver stand får udleveret en iPad, og alle data bliver indtastet på 
iPad'en. Inden eksamen får alle studerende tildelt et eksamensnummer, og dette eksamensnummer har de synligt på tøjet igennem hele eksamensforløbet. Når den studerende indfinder sig på en stand, kan eksaminator se eksamensnummeret, og indtaster dette i systemet. Da alle studerende er blevet lagt ind i systemet på forhånd, vil eksaminator efter indtastning af eksamensnummer få en tilbagemelding om, hvad den studerende, med dette eksamensnummer, hedder.

Selve eksaminationen kører i et fast interval med otte minutters eksamination og to minutters evaluering/pause. Dette forløb gentages indtil alle studerende er blevet eksamineret ved alle 14 stande. Inden eksamen er der lavet en plan, som specificerer, hvornår den studerende skal indfinde sig på en bestemt stand, og denne plan følges slavisk. Denne detailstyring gør det muligt at følge med i eksamensforløbet "live" og hurtig udpege mulige fejl og evt. problemer. Hvorved disse kan undgås eller rettes under selve eksamensforløbet.

I praksis er udarbejdelsen af brugerfladen til den digitale OSKE foregået ved, at eksaminatorer har givet konstruktiv kritik til designet af det digitale svarark i dennes tilblivelsesfase. Rangerende fra de helt små detaljer, som fx størrelsen af ikoner til forslag, som fx automatisering af sammentælling af checkscore på underpunkter til den faktuelle vurdering(Gaunt, Schmitz, \& Stolze, 2011). Nye ønsker, og behov er løbende blevet implementeret, bl.a. ønsket om at få et digitalt nedtællings ur, så eksaminator nemt kan holde styr på tiden.

Denne brugerinddragelse harmonerer fint med ideen med Participatory Design(Kensing \& Blomberg, 1998), og har været en hjælp til at imødekomme den skepsis som nogle eksaminatorer havde til både eksamensform og digitale løsning til afvikling heraf.

En anden fordel ved digitalisering af OSKE, er muligheden for at give de studerende noget kvalificeret feedback angående deres præstation. Til MCQ eksamenerne på Health, Aarhus Universitet er der udviklet et automatiseret feedback system, hvor de studerende kan logge ind på hjemmeside, og downloade en rapport over deres egen eksamenspræstation. OSKE er blevet føjet til dette system, således at de studerende kan få et overblik over, hvordan de har klaret sig på de enkelte stande. 


\begin{tabular}{|c|c|c|}
\hline Stand & Emne & Standscore i \% \\
\hline 1 & Kommunikation & 86.29 \\
\hline 3 & Derma - bensår & 36.00 \\
4 & Derma - atopisk eksem & 66.67 \\
5 & Klinisk genetik & 50.67 \\
6 & Pædiatri - 8 årig hovedpine & 79.56 \\
7 & Pædiatri - 1/2t resp-besvær & 37.33 \\
8 & Pædiatri - & 44.92 \\
10 & Pædiatri - Blå mærker & 42.33 \\
11 & Gyn-obs - Meno-metroagi & 87.56 \\
12 & Gyn-obs - udflåd & 65.00 \\
13 & Gyn-obs - obste & 55.33 \\
14 & Gyn-obs - prænatal diag. & 74.00 \\
15 & Socialmedicin & 36.00 \\
\hline
\end{tabular}

Figur 1. Eksempel på automatiseret feedback i forbindelse med OSKE eksamen forår 2014 (stand 9 og 16 er pausestande)

\begin{tabular}{|c|c|c|c|c|c|}
\hline Nr & Spørgsmál & Besvarelse & Tidspunkt & Tid brugt (sek) & Karakter \\
\hline 1 & 1 & Nedsat længdevækst & $09: 58: 53$ & 87 & \\
\hline 2 & 2 & $\begin{array}{l}\text { Rådgive om eksem. Give binyrebarkhormoncreme (gruppe 3) } \\
\text { og lave en anmeldelse på mistanke om arbejdsbetinget I } \\
\text { idelse. }\end{array}$ & $10: 00: 17$ & 84 & \\
\hline 3 & 3 & $\begin{array}{l}\text { På baggrund af det langvarige forløb og store skolefrav } \\
\text { ær laves underretning til kommunen i samarbejde med for } \\
\text { ældre. }\end{array}$ & $10: 01: 54$ & 97 & \\
\hline 4 & 4 & Blodprøve mhp. levertal og serum-galdesyre & $10: 02: 44$ & 50 & \\
\hline 5 & 5 & Scabies & $10: 03: 15$ & 31 & \\
\hline 6 & 6 & $\begin{array}{l}\text { Beskrive problemet i dødsattestens "Supplerende oplysni } \\
\text { nger". }\end{array}$ & 10:04:04 & 49 & \\
\hline 7 & 7 & Glemte p-piller & 10:04:15 & 11 & \\
\hline 8 & 8 & Ventrikel-septum defekt med venstre-højre shunt & $10: 06: 40$ & 145 & \\
\hline 9 & 9 & Strålebehandling og kemoterapi & 10:07:44 & 64 & \\
\hline
\end{tabular}

Figur 2. Eksempel på automatiseret feedback i forbindelse med MCQ eksamen forår 2014

At lave en lignende feedback med en papirbaseret eksamen er også muligt, men dette vil for hver gang kræve manuelle indtastninger. 
Med det digitaliserede system kan dette opnås ved at flytte en række tabeller mellem to databaser. Herefter kan de studerende selv downloade deres individuelle feedback.

Denne feedback imødekommer et ønske, som fremgår af den nyeste rapport om studiemiljøet på Health, Aarhus Universitet, hvor de studerene efterspurgt mere feedback(AarhusUniversitet, 2014), hvilke vi bl.a. er i stand til ved at anvende de digitale eksamensdata

\section{Digitale hjæelpemidler i det simulerede laboratorium}

Under OSKE på Health, Aarhus Universitet er der som nævnt 14 stande. Disse har vidt forskelligt indhold, men udmærker sig alle ved at være patient centreret, med fokus på mødet mellem (den kommende) læge og patienten (Horton-Szar \& Spencer, 2009; Skills, 2014). Vi beskriver her en case fra OSKE, med fokus på de digitale hjælpemidler, der indgår, samt fordele og ulemper ved disse.

En typisk opbygning af en case omfatter skriftligt information, som denne, hvor teksten den studerende får udleveret, lyder:

"Du er yngre læge i almen praksis. Din næste patient er førstegangs gravid i 31. uge. Hun har en akuttid, da hun har fået tiltagende hovedpine, samt hævelse af underben og fødder over de sidste dage.

Optag relevant og fokuseret sygehistorie. Foretag derefter relevant objektiv undersøgelse"

Patienten, som spilles af en skuespiller (en såkaldt simuleret patient), er på forhånd skriftligt og mundtligt instrueret $\mathrm{i}$, hvilke symptomer og svarmuligheder, der er relevante i denne case. I dette konkrete tilfælde simuleres et tidligt stadie af svangerskabsforgiftning, hvilket bl.a. medfører et forhøjet blodtryk. Et blodtryk som "patienten" ikke kan simulere. For at muliggøre, at den studerende kan foretage blodtryksmåling, erstattes skærmen på blodtryks apparatet med en iPad med app'en SimMon(Castle, 2009; "SimMon on the App Store on iTunes," n.d.), der via bluetooth er styret af en anden iDevice, hvorved det så er muligt at simulere det høje blodtryk, som "patient" har. 


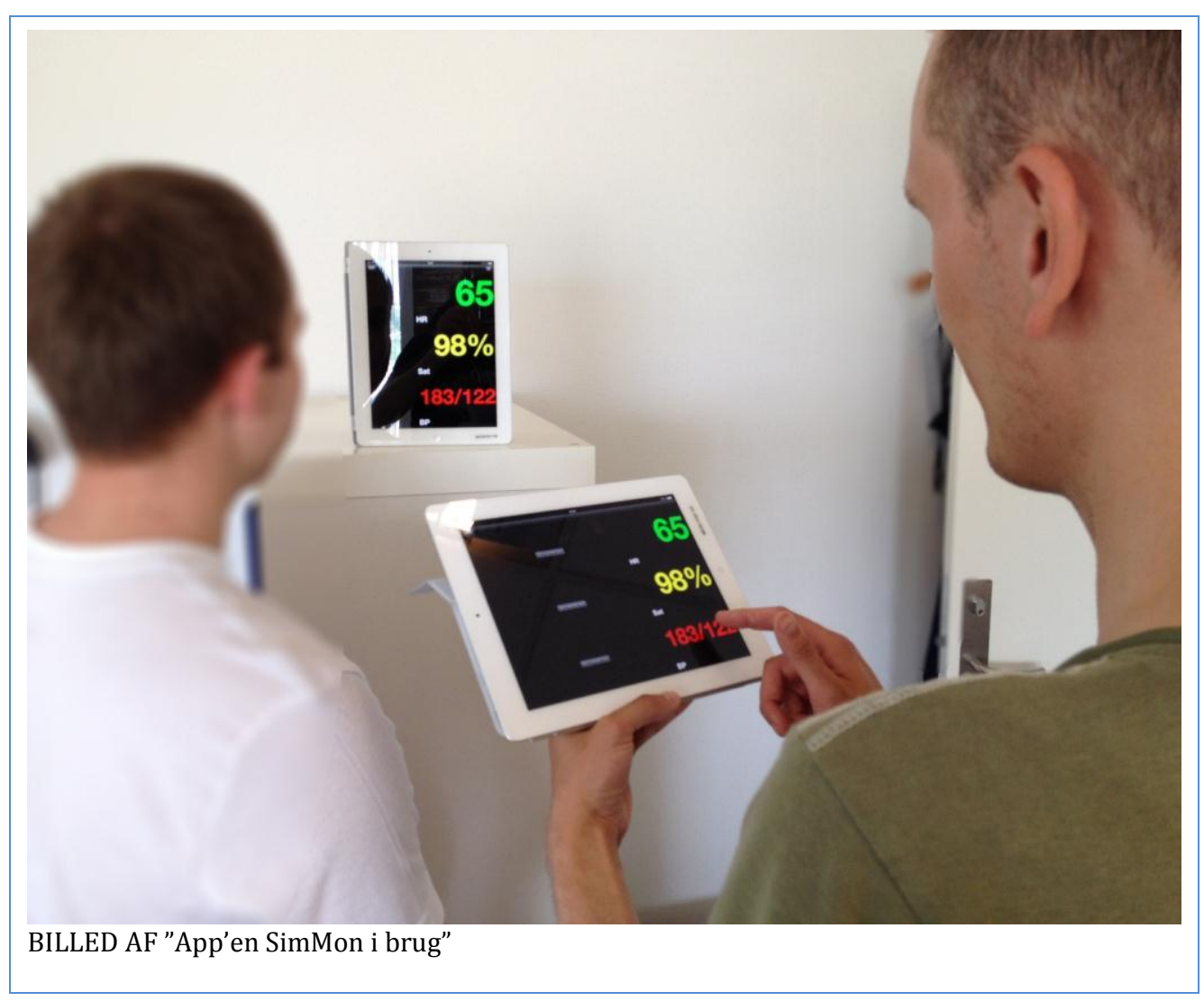

"Patienten" har, som en del af symptombilledet, vand i lungerne, hvilke man under normale omstændigheder kan høre med et stetoskop. Da dette, af gode grunde ikke kan simuleres af skuespilleren, benyttes et simuleret stetoskop, som eksempelvis kunne være SimScope WiFi ("SimScope WiFi (The Hybrid Simulator) - Cardionics," n.d.) eller Lecat's Ventriloscope ("Lecat's Ventriloscope - Products," n.d.). Begge stetoskoper muliggør, at den studerende får oplevelsen af abnorme (eller normale) hjerte- og/eller lunge-lyde, når skuespilleren stetoskoperes. I vores case høres fugtig knitrende/boblende lyde ved ind- og udånding. Lyden, som den studerende hører i stetoskopet, styres af skuespilleren, således at de trykker på knappen "ind", når de trækker vejret ind, og "ud", når de puster ud. 


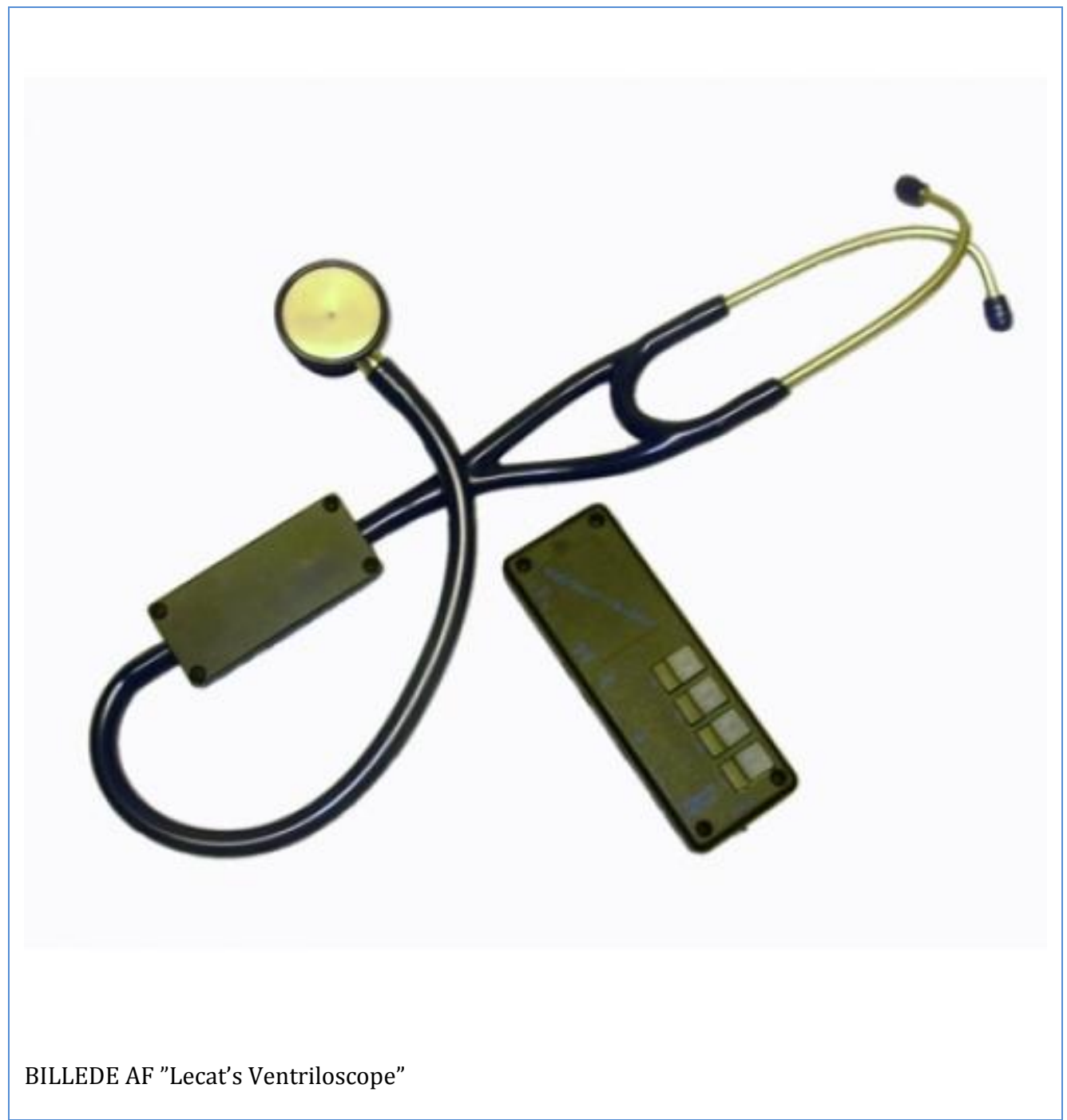

Med disse to digitale hjælpemidler får den studerende mulighed for at foretage en objektiv undersøgelse med de relevante kliniske fund, svarende til sygdoms- og symptombilledet for denne case.

Casen her sluttes af med opgaven: "Informer patienten om dine fund og det videre forløb ud fra disse fund"

\section{Diskussion}

Vi har, med digitaliseringen af OSKE, fået muligheden for at gennemføre nøjagtig den samme case/stand med 9 forskellige skuespillere, på tre forskellige fysiske lokalisationer, over et tidsrum på ca. 10 timer for ca. 200 medicinstuderende. Dette sikrer bedre en ensartet eksamen, som uden disse digitale hjælpemidler ville have været situeret i en væsentlig mere urealistisk kontekst, og derfor fjernt fra det, vi ønsker at teste. Det vi ønsker at teste er interaktionen mellem patienten, samt de studerendes evner til at omsætte deres faglige viden i praksis. 
Fordelene ved en digitalisering, skal holdes op imod de udfordringer en digitalisering giver

Et aspekt ved eksamen, som er blevet mere komplekst ved digitalisering er, at det kræver personer med IT kundskaber, for at administrere selve setup'et af eksamen. Det er IT personale, som skal klargøre eksamen, og efter endt eksamen flytte tabeller mellem databaser, for at muliggøre feedback til de studerende. Dette står i kontrast til den papirbaserede eksamen, hvor der "kun" skal printes papir til hver stand. Med al respekt for denne opgave, så er det dog en opgave, som alle - uden nævneværdige forudsætninger - kan varetage. En digital eksamen kræver personer, med IT kundskaber ud over det sædvanlige, for at overhovedet at igangsatte eksamenen.

Et andet aspekt ved en digital eksamen er, at teknikken kan svigte. Det er altid en risiko for, at uforudsete problemer opstår, hvorfor det er nødvendigt med en backup plan. Et eksempel på et sådant problem fra OSKE ved Health, Aarhus Universitet, hvor eksamen foregår på Skejby Sygehus. Hvilke medfører, at vi er nødt til at låne adgang til Internettet på det netværk, som Region Midt administrerer. Deres gæsteadgang gav os i første omgang kun adgang til Internettet i 8 timer, hvilke vi ikke var informeret om. Dette resulterede i at alle eksaminatorer mistede adgang til den digitale eksamen efter, da eksamenen alt i alt varer omkring 12 timer. For at imødekomme sådanne tekniske nedbrud er det nødvendigt at have en backup plan kørt i stillingen. Vores backup består i al sin enkelthed af et stykke papir, hvor eksaminatorerne kan skrive scoren for den enkelte studerende ned, og når Internetadgangen så reetableres, kan de indtaste deres bedømmelse i den digitale udgave af eksamenen.

Et tredje aspekt ved digital eksamen er, at der er behov for ekstra personale til klargøring af udstyr, samt generel IT hjælp under selve eksamenen. Da eksamen foregår over flere fysisk lokalisationer, er det nødvendigt at have flere personer udstationeret. Vi har løst opgaven ved at få ph.d. studerende til at varetage IT support opgaven, en opgave de har løst til fuld tilfredsstillelse.

Et fjerde aspekt er nødvendigheden af en stram tidsplan inden eksamenen. Udarbejdelsen af eksamensstande skal være færdig i god tid for at imødekomme behovet for at digitalisere standene. I 
modsætning til en papirbaseret udgave, så kræver en digitalisering at man får lagt den færdigudarbejdede stand ind i det digitale eksamenssystem, hvor man ved en papirbaseret eksamen "kun" skal printe eksamensopgaverne til standene ud. Til den første digitale OSKE var vores udmelding til opgavestillerne ikke klare nok, og de sidste stande blev først digitaliseret en time inden selve eksamensstart.

At standene ikke blev digitaliseret i tide var afledt af, at det faglige indhold i standene ikke var færdigt før en uge inden eksamen.

Efterfølgende har vi skærpet tonen overfor opgavestillerne og hvis deadline ikke overholdes foregår hele eksamenen for denne stand på papir, og efterfølgende manuelt indtastning af data pålægges denne stands eksaminatorer. Dette har vist sig at være en effektiv motivator for at overholde deadline.

\section{Perspektivering}

Den digitaliserede OSKE på Health, Aarhus Universitet, og det fortsatte fokus på det realistiske patientcentrerede møde, er muliggjort bl.a. ved skuespillere, fantomer, samt tekniske og digitale hjælpemidler. Fokus er, og skal forblive, på det realistiske patientcentrerede møde, da det ikke i sig selv er et mål at bruge diverse digitale hjælpemidler.

Simple løsninger, som beskrevet i ovenstående case, kræver ikke yderligere teknisk assistance. Dette gør sig derimod gældende for digitaliseret OSKE, der specielt før, men bestemt også under og efter, kræver betydelig og stabil teknisk assistance. Den tidsmæssige besparelse på sekretær opgaver i forbindelse med OSKE er indtil videre lagt i udvikling og afvikling af den digitale OSKE, og det forventes at det fremadrettet vil kræve et betydeligt ressourcetræk. Dog vurderes fordelene ved den digitale OSKE klart at opveje ulemperne, og det forventede fremadrettede ressourcetræk.

Generelle overvejelser ved implementering af digitale hjælpemidler, og medier i forbindelse med undervisning eller eksamen, hvor er et stort antal underviserer/eksaminatorer er slutbrugerne, skal de eller en del af dem konsulteres under udviklingen således at de fra starten af følger et medejerskab. Dette har været gældende for OSKE på Health, Aarhus Universitet og vil formentlig være det i andre sammenhæng. 


\section{Referencer}

Bygningsstyrelsen, U. (2010). Rapport om digitale eksaminer på universiteterne - Styrelsen for Universiteter og Internationalisering. Universitets- og Bygningsstyrelsen. Retrieved from http://www.ubst.dk/publikationer

Castle, N. (2009). SimMon Medical Simulation App. Retrieved September 25, 2014, from http://castleandersen.dk/apps/simmon/

Gaunt, K., Schmitz, F., \& Stolze, M. (2011). Choose popovers over buttons for iPad questionnaires. Human-Computer Interaction-INTERACT ..., 533-540. Retrieved from http://link.springer.com/chapter/10.1007/978-3-642-23771-3_40

Harden, R. M. (2013). MedEdWorld - eOSCE: A three component digital OSCE process. Retrieved September 25, 2014, from http://www.mededworld.org/Learning-Technology/EquipmentItems/eOSCE-A-three-component-digital-OSCE-process.aspx

Horton-Szar, D., \& Spencer, J. (2009). OSCEs in Medicine and Surgery (p. 221). Mosby, Inc.

III, V. R. (2007). Mulighedernes samfund, (November). Retrieved from http://www.stm.dk/publikationer/Regeringsgrundlag2007/index.htm

Jalali, B. A., Trottier, D., \& Tremblay, M. (2012). Administering a Gross Anatomy Exam Using Mobile Technology How one medical school made the switch from paper to paperless . elearn Magazine : Administering a Gross Anatomy Exam Using Mobil ..., 10-13.

Kensing, F., \& Blomberg, J. (1998). Participatory design: Issues and concerns. Computer Supported Cooperative Work (CSCW), (1993), 167185. Retrieved from http://link.springer.com/article/10.1023/A:1008689307411

Lecat's Ventriloscope - Products. (n.d.). Retrieved May 30, 2014, from http://www.ventriloscope.com/simply-sim-products.php

Ortind, E., Krogh, K., \& Dahl, M. R. (2013). Udfordringer med digital Multiple Choice Questions , som eksamensform på medicin studiet, Health , Aarhus Universitet. Læring \& Medier, (10), 1-22.

Schmitz, F., Zimmermann, P., Gaunt, K., Stolze, M., \& Schär, S. G. (2011). Electronic rating of objective structured clinical examinations: mobile digital forms beat paper and pencil checklists in a comparative study (pp. 501-512). Retrieved from http://link.springer.com/chapter/10.1007/978-3-642-25364-5_35

SimMon on the App Store on iTunes. (n.d.). Retrieved May 30, 2014, from https://itunes.apple.com/us/app/simmon/id364731597?mt=8

SimScope WiFi (The Hybrid Simulator) - Cardionics. (n.d.). Retrieved May 30, 2014, from http://www.cardionics.com/simscope.html 
Skills, 0. (2014). Rectal (PR) Examination OSCE Station Guide. Retrieved September 25, 2014, from http://www.osceskills.com/elearning/subjects/rectal-examination/

Økonomistyrelsen. (2011). DEN DIGITALE VEJ TIL FREMTIDENS VELFÆRD. Rosendahls - Schultz Distribution. Retrieved from www.fm.dk, www.kl.dk, www.regioner.dk

AarhusUniversitet. (2014). Studiemiljø2014 Aarhus Universitet Rapport nr 4. 